\title{
Brucella ceti sp. nov. and Brucella pinnipedialis sp. nov. for Brucella strains with cetaceans and seals as their preferred hosts
}

\author{
Correspondence \\ Geoffrey Foster \\ Geoffrey.Foster@sac.co.uk
}

\author{
Geoffrey Foster, ${ }^{1}$ Bjorn S. Osterman, ${ }^{2}$ Jacques Godfroid, ${ }^{3}$ \\ Isabelle Jacques ${ }^{4,5}$ and Axel Cloeckaert ${ }^{4}$ \\ ${ }^{1}$ SAC Veterinary Services, Inverness IV2 4JZ, UK \\ ${ }^{2}$ Department of Clinical Microbiology, Karolinska University Hospital, MTC, Stockholm SE-17176, \\ Sweden \\ ${ }^{3}$ Faculty of Veterinary Science, Department of Veterinary Tropical Diseases, University of Pretoria, \\ Onderstepoort 0110, South Africa \\ ${ }^{4}$ INRA, UR1282, Infectiologie Animale et Santé Publique, IASP, Nouzilly, F-37380, France \\ ${ }^{5}$ Institut Universitaire de Technologie, Université François Rabelais, 29 rue du Pont-Volant, \\ 37082 Tours cedex 2, France
}

\begin{abstract}
Small Gram-negative cocco-bacilli resembling Brucella strains have been reported from marine mammals since the mid-1990s. Their placement in the genus Brucella has been supported by the following characteristics: they are aerobic, non-motile and catalase-positive, do not produce acid from carbohydrates and have a DNA-DNA relatedness value of $>77 \%$ with the six established members of the genus. Twenty-eight European isolates of the genus Brucella from marine mammals were distinguished from the six recognized species by their pattern of utilization of eleven substrates in oxidative metabolism tests and phage lysis. The 28 strains could be further separated into two groups with cetaceans and seals as their respective preferred hosts on the basis of molecular methods and on differences in the metabolism of L-arabinose, D-galactose and D-xylose. The names Brucella cetisp. nov. and Brucella pinnipedialis sp. nov. are proposed for the isolates from cetaceans and seals, respectively. The type strain of Brucella ceti sp. nov. is NCTC $12891^{\top}$ (=BCCN 94-74 ${ }^{\top}$ ) and the type strain of Brucella pinnipedialis sp. nov. is NCTC $12890^{\top}\left(=\mathrm{BCCN} 94-73^{\top}\right)$.
\end{abstract}

The genus Brucella contains aerobic, intracellular bacteria that can infect many species of animals and man. Corbel \& Brinley-Morgan (1984) listed six species in the genus; however, subsequent DNA-DNA hybridization studies demonstrated that the genus Brucella is a highly homogeneous group ( $>90 \%$ DNA-DNA relatedness) (Verger et al., 1985, 1987). A proposal that this genus should comprise only one genomic species (Verger et al., 1985, 1987) was accepted by the Brucella Taxonomy Subcommittee with some guardedness (Manchester, UK, 1986; Corbel, 1988). This proposal did not gain acceptance amongst brucellosis researchers, however, and classification of Brucella strains into six species, with particular emphasis on the preferential host (Corbel \& Brinley-Morgan, 1984), was still favoured. Thus, the outcome of the Manchester meeting-sanctioned taxonomic opinion that the genus Brucella was monospecific was the use of two systems of nomenclature, one for taxonomic purposes and one, using vernacular names, for non-taxonomic purposes. The following, poorly attended, Brucella Taxonomy
Subcommittee meeting in Osaka, Japan, in 1990 was not reported. A Subcommittee Correspondence Report 19911993 (Gargani \& López-Merino, 2006) was followed by a meeting in Prague, Czech Republic, in 1994 (Corbel \& Moriyón, 2006). After a period of inactivity, a convened Brucella Subcommittee meeting was held in Nimes, France, in 2000 (MacMillan, 2006), with the intention of relaunching the Brucella Taxonomy Subcommittee; a feat that was not finally achieved for another three years.

The six previously recognized species of the genus Brucella can be distinguished on the basis of preferred host, phenotype and genotype. In addition, the seriousness of human Brucella infections, the political significance of the disease for agriculture and the potential role for Brucella as an agent of bioterrorism are strong supportive reasons for the widely held view that the original six species format should prevail. When the International Committee on the Systematics of Prokaryotes Subcommittee on the Taxonomy of Brucella met in 2003 (in Pamplona, Spain), 
there was a unanimous verdict to return to the six species taxonomy for the genus Brucella. This lead to a recommendation from the Brucella Subcommittee that there should be a return to the pre-1986 taxonomy of the genus Brucella (Osterman \& Moriyón, 2006). This Subcommittee recommendation implies the reapproval of the six classical Brucella nomenspecies with their recognized biovars; the classical names related to these six species having been validly published in the Approved List of Bacterial Names (Skerman et al., 1980, 1989). In this context, reference should also be made to the Bacteriological Code (1990 Revision) (Lapage et al., 1992) and an updated Taxonomic Note (Tindall et al., 2006).

Brucella infections of terrestrial mammals have long been recognized and have been researched extensively; however, it was only during the last few years of the twentieth century that the first reports of Brucella species from animals living in the marine environment were made. The first marine mammal isolations of Brucella strains came from common seals (Phoca vitulina), a porpoise (Phocoena phocoena) and a common dolphin (Delphinus delphis) in Scotland (Ross et al., 1994) and a captive bottlenose dolphin (Tursiops truncatus) in the USA (Ewalt et al., 1994). Since these first reports, there have been many more isolations and the range of hosts has expanded significantly (Foster et al., 2002). Additional species from which bacteriological cultures have proved positive include the Atlantic white-sided dolphin (Lagenorhynchus acutus), striped dolphin (Stenella coeruleoalba) (Foster et al., 1996), minke whale (Balaenoptera acutorostrata) (Clavareau et al., 1998; Foster et al., 2002), hooded seal (Cystophora cristata), grey seal (Halichoerus grypus) (Foster et al., 1996), Pacific harbour seal (Phoca vitulina richardsi) (Garner et al., 1997), ringed seal (Phoca hispida), harp seal (Phoca groenlandica) (Forbes et al., 2000; Maratea et al., 2003) and a European otter (Lutra lutra) (Foster et al., 1996). In addition, there have also been reports of human infections with strains from marine mammals (Brew et al., 1999; Sohn et al., 2003; McDonald et al., 2006).

Since their discovery, Brucella strains from marine mammals have been subjected to a range of characterization tests which have compared them with each other and also with the terrestrial Brucella species. Representative Brucella strains of marine mammals, which include the designated type strains of $B$. ceti sp. nov. and $B$. pinnipedialis sp. nov., have been shown by DNA-DNA hybridization to be related to the six classical Brucella nomenspecies at a level of $>77 \%$ DNA-DNA relatedness. The type strains of all these species form a homogeneous DNA-DNA relatedness group (Verger et al., 2000; Wayne et al., 1987). These results may be interpreted as evidence for the two proposed novel marine mammal Brucella species being affiliated to the genus Brucella. The appearance of these novel Brucella strains fits with previous descriptions of members of the genus Brucella made by Corbel \& Brinley-Morgan $(1975,1984)$ and by Corbel \& Banai (2005). The Brucella strains from marine mammals are small Gram-negative cocci, coccobacilli or short rods, $0.5-0.7 \mu \mathrm{m}$ in diameter and $0.6-1.5 \mu \mathrm{m}$ in length, nonmotile, aerobic, catalase-positive, oxidase-positive, able to reduce nitrates, urease-positive, indole-negative, negative for gelatin liquefaction, do not produce acid from carbohydrates in conventional media and possess Brucella antigens, as demonstrated by reactions with Brucella-specific antisera.

Jahans et al. (1997) managed to distinguish the marine mammal strains from the terrestrial species of the genus Brucella on the basis of a substrate-specific oxidative metabolism test and suggested that they may belong to a separate species for which the name 'Brucella maris' was suggested but not formally proposed. Jahans further demonstrated that galactose metabolism served as a useful test to separate cetacean-derived species from those derived from seals. Ribotyping further suggested that marine strains of the genus Brucella may represent a separate group on the basis of their rRNA gene HindIII restriction pattern (Verger et al., 2000). Other distinctive characteristics at the molecular and genomic level have been provided by IS711 DNA fingerprinting which showed that a higher number of IS711 copies occur in the genomes of Brucella isolates from marine mammals than in strains isolated from land mammals (Clavareau et al., 1998; Bricker et al., 2000). A specific marker of marine mammal isolates has been identified, consisting of an IS711 element downstream of the bp26 gene (Cloeckaert et al., 2000). Most recently, a study of DNA polymorphism at the omp2 locus showed that the isolates from marine mammals can be classified into two major groups, one comprising isolates from seals that carry one copy of both the omp2a and omp $2 b$ genes and another group comprising the cetacean isolates carrying two copies of the omp2b gene (Cloeckaert et al., 2001). Both copies of the omp2 gene were shown to contain motifs typical of marine mammal isolates. 16S rRNA gene sequence data, as well as recA gene sequences, identify the strains from marine mammals as belonging to the genus Brucella (Scholz et al., 2006).

With respect to the classification of species of the genus Brucella according to their preferential host, two new species names have been suggested, but not validly published: ' $B$. pinnipediae' (for isolates from seals) and 'B. cetaceae' (for isolates from cetaceans) (Cloeckaert et al., 2001). Furthermore, development of an infrequent restriction site-PCR (IRS-PCR) method, taking into account the higher number of IS711 elements in the genome of isolates from marine mammals compared with Brucella species from terrestrial mammals, allowed the classification of the marine mammal isolates into two distinct clusters of strains. These two clusters were also distinct from the clusters representing the recognized Brucella species from terrestrial mammals (Cloeckaert et al., 2003). These two clusters of strains correlated well with the hosts from which they had been isolated, i.e. a cluster of isolates from cetaceans and a cluster of isolates from pinnipeds. Therefore, IRS-PCR confirmed the previous classification 
of isolates from marine mammals, based on DNA polymorphism at the omp2 locus and their preferential hosts, into two novel species of the genus Brucella: 'Brucella cetaceae' for cetacean isolates and 'Brucella pinnipediae' for pinniped isolates (Cloeckaert et al., 2001).

Studies by Vizcaíno et al. identified an additional specific marker for ' $B$. cetaceae' found in most cetacean isolates consisting of a $1.7 \mathrm{~kb}$ inversion including a gene coding for one of the Omp25/Omp31 family of proteins (Vizcaíno et al., 2004). More recently, Jacques et al. (2007) used oxidative metabolism to confirm the findings of Jahans and provide further support for these two novel species of the genus Brucella. The approval of the taxonomic rank of species for each of these two groups of Brucella strains from marine mammals is in line with the recommendations made by the ad hoc Committees on approaches to taxonomy (Wayne et al., 1987; Murray et al., 1990; Stackebrandt et al., 2002) and with our current understanding of the evolution of the genus and of the relevant criteria for inclusion in this group (Moreno et al., 2002).
In view of the data presented above and in the descriptions of the novel isolates from marine mammals (given below), the characteristics of the two novel species meet the criteria for inclusion in the genus Brucella and conform to the minimal standards for the description of novel Brucella species as laid down by the Brucella Taxonomy Subcommittee (Corbel \& Brinley-Morgan, 1975). The recommended investigation procedures have been used and have provided results that concur with the requirements for members of the genus Brucella as regards particular morphological features observable by electron microscopy, cultural characteristics and colony morphologies. Strains of the two novel species are obligate aerobes with an oxidative metabolism and have oxidative metabolic profiles that enable inter-species differentiation. The Brucella antigenic profiles and results from Brucella phage sensitivity tests, as well as results from classical Brucella biochemical tests (Table 1), also confirm their assignment to the genus Brucella. The facultatively intracellular behaviour of the proposed novel species is also in congruence with that of recognized members of the genus

Table 1. Differential characteristics of Brucella ceti sp. nov., Brucella pinnipedialis sp. nov. and other members of the genus Brucella

Data from Alton et al. (1975, 1988); Corbel \& Banai (2005); Jacques et al. (2007); Meyer \& Cameron (1961); Verger \& Grayon (1977). Results are expressed as $\mathrm{QO}_{2}(\mathrm{~N})$ values corresponding to microlitres of oxygen uptake per milligram of bacterial nitrogen per hour.,$+ \mathrm{QO}_{2}(\mathrm{~N})$ over 100 for all strains; -, $\mathrm{QO}_{2}(\mathrm{~N})$ below 100 for all strains; D, doubtful, some strains showing $\mathrm{QO}_{2}(\mathrm{~N})$ over 100, some strains showing $\mathrm{QO}_{2}(\mathrm{~N})$ below 100 ; $\mathrm{NL}$, no lysis; L, lysis; RTD, routine test dilution.

\begin{tabular}{|c|c|c|c|c|c|c|c|c|c|c|c|c|}
\hline \multirow[t]{2}{*}{ Characteristic } & \multirow{2}{*}{$\begin{array}{c}\text { B. } \text { ceti } \\
\text { (17 strains) }\end{array}$} & \multirow{2}{*}{$\begin{array}{l}\text { B. pinnipedialis } \\
\text { (11 strains) }\end{array}$} & \multirow{2}{*}{$\begin{array}{c}\text { B. } \\
\text { melitensis }\end{array}$} & \multirow{2}{*}{$\begin{array}{c}\text { B. } \\
\text { abortus }\end{array}$} & \multicolumn{5}{|c|}{ B. suis biovars } & \multirow{2}{*}{$\begin{array}{c}\text { B. } \\
\text { neotomae }\end{array}$} & \multirow{2}{*}{$\begin{array}{c}\text { B. } \\
\text { ovis }\end{array}$} & \multirow{2}{*}{$\begin{array}{c}\text { B. } \\
\text { canis }\end{array}$} \\
\hline & & & & & 1 & 2 & 3 & 4 & 5 & & & \\
\hline Urease & + & + & + & $+^{*}$ & + & + & + & + & + & + & - & + \\
\hline \multicolumn{13}{|c|}{ Lysis by phage at RTD: } \\
\hline $\mathrm{Tb}$ & $\mathrm{NL}$ & $\mathrm{NL} \dagger$ & NL & $\mathrm{L}$ & $\mathrm{NL}$ & $\mathrm{NL}$ & $\mathrm{NL}$ & $\mathrm{NL}$ & $\mathrm{NL}$ & $\mathrm{D}$ & NL & $\mathrm{NL}$ \\
\hline $\mathrm{Wb}$ & $\mathrm{L}$ & $\mathrm{L}$ & $\mathrm{NL}$ & $\mathrm{L}$ & $\mathrm{L}$ & $\mathrm{L}$ & $\mathrm{L}$ & $\mathrm{L}$ & $\mathrm{L}$ & $\mathrm{L}$ & NL & $\mathrm{NL}$ \\
\hline $\mathrm{Iz}$ & $\mathrm{L}$ & $\mathrm{L}$ & $\mathrm{L}$ & $\mathrm{L}$ & $\mathrm{L}$ & $\mathrm{L}$ & $\mathrm{L}$ & $\mathrm{L}$ & $\mathrm{L}$ & $\mathrm{L}$ & NL & $\mathrm{NL}$ \\
\hline $\mathrm{R} / \mathrm{C}$ & NL & $\mathrm{NL}$ & $\mathrm{NL}$ & $\mathrm{NL}$ & $\mathrm{NL}$ & $\mathrm{NL}$ & $\mathrm{NL}$ & $\mathrm{NL}$ & $\mathrm{NL}$ & $\mathrm{NL}$ & $\mathrm{L}$ & $\mathrm{L}$ \\
\hline \multicolumn{13}{|l|}{ Oxidation of: } \\
\hline L-Alanine & - & - & + & + & $\mathrm{D}$ & - & $\mathrm{D}$ & - & - & - & $\mathrm{D}$ & - \\
\hline L-Arabinose & + & - & - & + & + & + & - & - & - & + & - & - \\
\hline L-Arginine & - & - & - & - & + & + & + & + & + & - & - & + \\
\hline L-Asparagine & - & - & + & + & - & $\mathrm{D}$ & - & - & $\mathrm{D}$ & + & + & - \\
\hline $\begin{array}{l}\text { meso- } \\
\text { Erythritol }\end{array}$ & $\mathrm{D}$ & + & + & + & + & + & + & + & + & + & - & $\mathrm{D}$ \\
\hline D-Galactose & + & - & - & + & + & + & - & - & - & + & - & - \\
\hline $\begin{array}{l}\text { L-Glutamic } \\
\text { acid }\end{array}$ & + & + & + & + & $\mathrm{D}$ & + & + & + & + & + & + & + \\
\hline L-Lysine & - & - & - & - & + & $\mathrm{D}$ & $\mathrm{D}$ & $\mathrm{D}$ & $\mathrm{D}$ & - & - & $\mathrm{D}$ \\
\hline DL-Ornithine & - & - & - & - & + & + & + & + & + & - & - & + \\
\hline D-Ribose & + & + & - & + & + & + & + & + & + & $\mathrm{D}$ & - & + \\
\hline D-Xylose & + & - & - & - & + & $\mathrm{D}$ & $\mathrm{D}$ & $\mathrm{D}$ & $\mathrm{D}$ & - & - & - \\
\hline Preferred host & Cetaceans & Seals & $\begin{array}{l}\text { Sheep, } \\
\text { goats }\end{array}$ & Cattle & Swine & $\begin{array}{r}\text { Swine, } \\
\text { hares }\end{array}$ & Swine & Reindeer & Rodents & $\begin{array}{l}\text { Desert } \\
\text { wood rat }\end{array}$ & Sheep & Dogs \\
\hline
\end{tabular}

*Except for reference strain 544 and occasional field strains which are negative.

$\dagger$ Lysis occurs with a few strains. 
Brucella, as are the special characteristics of specific host preferences and virulence-pathogenicity.

The proposals of these two groups of marine mammal Brucella strains as being of the taxonomic rank of species of the genus Brucella are based on investigations according to the Subcommittee recommendation (Corbel \& BrinleyMorgan, 1975) 'that strains should be classified into species on the basis of (i) preferred natural host, (ii) sensitivity to Brucella phages, and (iii) oxidative metabolic profiles'. The results of molecular investigations are also included. The proposal is in line with decisions (focusing on new methods of pheno-genotypic analysis) taken by the Subcommittee at the 2003 Pamplona meeting (Osterman \& Moriyón, 2006), where the earlier acknowledged importance of host-preference and virulence-pathogenicity for the delineation of species of the genus Brucella was reemphasized. The results are based on phenotypic and molecular tests on over 30 isolates collected from marine mammals in several European countries, thereby providing clear evidence of host preference for cetacean- and pinniped-derived strains, respectively.

Following the return to the six-species taxonomy based on the unanimous verdict of the International Subcommittee on the Taxonomy of Brucella (Osterman \& Moriyón, 2006) and the reasons presented above, we formally propose two novel species of the genus Brucella for strains from marine mammals (with corrected etymology). The name Brucella ceti sp. nov. is proposed for Brucella strains with cetaceans as their preferred host and the name Brucella pinnipedialis sp. nov. is proposed for Brucella strains with pinnipeds as their preferred host.

\section{Description of Brucella ceti sp. nov.}

Brucella ceti [ce.ti. L. n. cetus large sea animal (whale, porpoise, dolphin); L. gen. n. ceti of a large sea animal].

Cocci, coccobacilli or short rods, $0.5-0.7 \mu \mathrm{m}$ in diameter and $0.6-1.5 \mu \mathrm{m}$ in length. Arranged singly and, less frequently, in pairs, short chains or small groups. Gramnegative. Non-motile; does not produce flagella. Aerobic. Colonies on Columbia sheep blood agar and Farrell's medium are normally visible after 3-4 days and are raised, convex, circular and entire with a diameter of $0.5-1.0 \mathrm{~mm}$. Non-haemolytic. Nitrate reductase is produced. Most strains do not require supplementary $\mathrm{CO}_{2}$ for growth. Growth is improved by the addition of serum or blood. Colonies on serum-glucose agar are transparent, raised, convex, with an entire edge and a smooth shiny surface and appear as a pale honey colour by transmitted light. Optimum temperature is $37^{\circ} \mathrm{C}$. Growth occurs between 20 and $40{ }^{\circ} \mathrm{C}$. Optimum $\mathrm{pH}$ is between 6.6 and 7.4. Catalase-, oxidase- and urease-positive. $\mathrm{H}_{2} \mathrm{~S}$ negative. Lglutamic acid, L-arabinose, D-galactose, D-ribose and Dxylose are oxidized, but L-alanine, L-asparagine, L-arginine, DL-ornithine and L-lysine are not oxidized. meso-Erythritol may or may not be oxidized. Cultures are lysed by Iz and $\mathrm{Wb}$ phages, but no lysis occurs with $\mathrm{Tb}$ and $\mathrm{R} / \mathrm{C}$ phages. $\mathrm{A}$ antigen dominant. The preferred hosts are porpoises, dolphins and whales in which a range of pathologies occur.

The type strain, NCTC $12891^{\mathrm{T}}\left(=\mathrm{BCCN} 94-74^{\mathrm{T}}\right)$, was isolated from a skin lesion on a harbour porpoise.

\section{Description of Brucella pinnipedialis sp. nov.}

Brucella pinnipedialis (pin.ni.ped.i.a'lis. N.L. fem. adj. pinnipedialis pertaining to pinnipeds).

Cocci, coccobacilli or short rods, $0.5-0.7 \mu \mathrm{m}$ in diameter and $0.6-1.5 \mu \mathrm{m}$ in length. Arranged singly and, less frequently, in pairs, short chains or small groups. Gramnegative. Non-motile; does not produce flagella. Aerobic. Colonies on Columbia sheep blood agar are normally visible after 3-4 days and are raised, convex, circular, entire and non-haemolytic with a diameter of $0.5-1.0 \mathrm{~mm}$. Growth on Farrell's medium is typically slower (7-10 days) or absent. Nitrate reductase is produced. Most strains require supplementary $\mathrm{CO}_{2}$ for growth. Growth is improved by the addition of serum or blood. Colonies on serum-glucose agar are transparent, raised, convex, with an entire edge and a smooth shiny surface and appear as a pale honey colour by transmitted light. Optimum temperature is $37{ }^{\circ} \mathrm{C}$. Growth occurs between 20 and $40{ }^{\circ} \mathrm{C}$. Optimum pH is between 6.6 and 7.4. Catalase-, oxidaseand urease-positive. $\mathrm{H}_{2} \mathrm{~S}$ negative. In oxidative metabolism tests, L-glutamic acid, D-ribose and meso-erythritol are oxidized, but L-alanine, L-arginine, L-asparagine, DLornithine, L-lysine, L-arabinose, D-galactose and D-xylose are not oxidized. Cultures are lysed by Iz and $\mathrm{Wb}$ phages, but no lysis occurs with R/C. A small number of strains exhibit lysis with the Tb phage. A antigen dominant. The preferred hosts are seals, in which the strains cause a range of pathologies.

The type strain, NCTC $12890^{\mathrm{T}}\left(=\mathrm{BCCN} 94-73^{\mathrm{T}}\right)$, was isolated from the spleen of a common seal (Phoca vitulina).

\section{Acknowledgements}

We want to express our gratitude to Alastair MacMillan for the successful resurrection of the ICSP Subcommittee on the Taxonomy of Brucella, in this way making possible the Brucella Taxonomy Subcommittee recommendation for a return to pre-1986, classical Brucella taxonomy, thereby paving the way for each of the two groups of marine mammal Brucella strains to be approved as being of the taxonomic rank of species. We also wish to express our gratitude to Ignacio Moriyón and Mike Corbel for helpful discussions concerning this manuscript. The Scottish Strandings Scheme receives funding from the UK Department of Environment, Farming and Rural Affairs.

\section{References}

Alton, G. G., Jones, L. M. \& Pietz, D. E. (1975). Laboratory Techniques in Brucellosis. WHO Monograph Series no. 55. Geneva, Switzerland: WHO.

Alton, G. G., Jones, L. M., Angus, R. D. \& Verger, J. M. (1988). Techniques for the Brucellosis Laboratory. Paris, France: INRA. 
Brew, S. D., Perrett, L. L., Stack, J. A., MacMillan, A. P. \& Staunton, N. J. (1999). Human exposure to Brucella recovered from a sea mammal. Vet Rec 144, 483.

Bricker, B. J., Ewalt, D. R., MacMillan, A. P., Foster, G. \& Brew, S. (2000). Molecular characterization of Brucella strains isolated from marine mammals. J Clin Microbiol 38, 1258-1262.

Clavareau, C., Wellemans, V., Walravens, K., Tryland, M., Verger, J.-M., Grayon, M., Cloeckaert, A., Letesson, J. J. \& Godfroid, J. (1998). Phenotypic and molecular characterization of a Brucella strain isolated from a minke whale (Balaenoptera acutorostrata). Microbiology 144, 3267-3273.

Cloeckaert, A., Grayon, M. \& Grepinet, O. (2000). An IS711 element downstream of the $b p 26$ gene is a specific marker of Brucella spp. isolated from marine mammals. Clin Diagn Lab Immunol 7, 835-839.

Cloeckaert, A., Verger, J.-M., Grayon, M., Paquet, J. Y., Garin-Bastuji, B., Foster, G. \& Godfroid, J. (2001). Classification of Brucella spp. isolated from marine mammals by DNA polymorphism at the omp2 locus. Microbes Infect 3, 729-738.

Cloeckaert, A., Grayon, M., Grépinet, O. \& Sidi Boumedine, K. (2003). Classification of Brucella strains isolated from marine mammals by infrequent restriction site-PCR and development of specific PCR identification tests. Microbes Infect 5, 593-602.

Corbel, M. J. (1988). International Committee on Systematic Bacteriology; Subcommittee on the taxonomy of Brucella. Report of the meeting, 5 September 1986. Manchester, England. Int J Syst Bacteriol 38, 450-452.

Corbel, M. J. \& Banai, M. B. (2005). Genus Brucella. In Bergey's Manual of Systematic Bacteriology, 2nd edn, pp. 370-386. Edited by D. J. Brenner, N. R. Krieg \& J. T. Staley. New York: Springer.

Corbel, M. J. \& Brinley-Morgan, W. J. (1975). Proposal for minimal standards for descriptions of new species and biotypes of the genus Brucella. Int J Syst Bacteriol 25, 83-89.

Corbel, M. J. \& Brinley-Morgan, W. J. (1984). Genus Brucella. In Bergey's Manual of Systematic Bacteriology, vol. 1, pp. 377-388. Edited by N. R. Krieg \& J. G. Holt. Baltimore: Williams and Wilkins.

Corbel, M. J. \& Moriyón, I. (2006). International Committee on Systematic Bacteriology; Subcommittee on the taxonomy of Brucella: Minutes of the meeting, 5 and 7 July 1994, Prague, Czech Republic. Int J Syst Evol Microbiol 56, 1169-1170.

Ewalt, D. R., Payeur, J. B., Martin, B. M., Cummins, D. R. \& Miller, G. M. (1994). Characteristics of a Brucella species from a bottlenose dolphin (Tursiops truncatus). J Vet Diagn Invest 6, 448-452.

Forbes, L. B., Nielsen, O., Measures, L. \& Ewalt, D. R. (2000). Brucellosis in ringed seals and harp seals from Canada. J Wildl Dis 36, 595-598.

Foster, G., Jahans, K. L., Reid, R. J. \& Ross, H. M. (1996). Isolation of Brucella species from cetaceans, seals and an otter. Vet Rec 138, 583-586.

Foster, G., MacMillan, A. P., Godfroid, J., Howie, F., Ross, H. M., Cloeckaert, A., Reid, R. J., Brew, S. \& Patterson, I. A. P. (2002). A review of Brucella sp. infection of sea mammals with particular emphasis on isolates from Scotland. Vet Microbiol 90, 563-580.

Gargani, G. \& López-Merino, A. (2006). International Committee on Systematic Bacteriology; Subcommittee on the taxonomy of Brucella: Correspondence Report (Interim Report), 1991-1993. Int J Syst Evol Microbiol 56, 1167-1168.

Garner, M. M., Lambourn, D. M., Jeffries, S. J., Hall, P. B., Rhyan, J. C., Ewalt, D. R., Polzin, L. M. \& Cheville, N. F. (1997). Evidence of Brucella infection in Parafilaroides lungworms in a Pacific harbor seal (Phoca vitulina richardsi). J Vet Diagn Invest 9, 298-303.

Jacques, I., Grayon, M. \& Verger, J.-M. (2007). Oxidative metabolic profiles of Brucella strains isolated from marine mammals: contribution to their species classification. FEMS Microbiol Lett 270, 245-249.
Jahans, K. L., Foster, G. \& Broughton, E. S. (1997). The characteristics of Brucella strains isolated from marine mammals. Vet Microbiol 57, 373-382.

Lapage, S. P., Sneath, P. H. A., Lessel, E. F., Skerman, V. B. D., Seeliger, H. P. R. \& Clark, W. A. (editors) (1992). International Code of Nomenclature of Bacteria (1990 Revision). Bacteriological Code. Washington, DC: American Society for Microbiology.

MacMillan, A. (2006). International Committee on Systematic Bacteriology; Subcommittee on the taxonomy of Brucella: Minutes of the meeting, 9 September 2000, Nimes, France. Int J Syst Evol Microbiol 56, 1171.

Maratea, J., Ewalt, D. R., Frasca, S., Jr, Dunn, J. L., De Guise, S., Szkudlarek, L., St. Aubin, D. J. \& French, R. A. (2003). Evidence of Brucella sp. infection in marine mammals stranded along the coast of Southern New England. J Zoo Wildl Med 34, 256-261.

McDonald, W. L., Jamaludin, R., Mackereth, G., Hansen, M., Humphrey, S., Short, P., Taylor, T., Swingler, J., Dawson, C. E. \& other authors (2006). Characterisation of a Brucella strain as a marine-mammal type despite isolation from a patient with spinal osteomyelitis in New Zealand. J Clin Microbiol 44, 4363-4370.

Meyer, M. E. \& Cameron, H. S. (1961). Metabolic characterization of the genus Brucella. I. Statistical evaluation of the oxidative rates by which type I of each species can be identified. J Bacteriol 82, 387-395.

Moreno, E., Cloeckaert, A. \& Moriyón, I. (2002). Brucella evolution and taxonomy. Vet Microbiol 90, 209-227.

Murray, R. G. E., Brenner, D. J., Colwell, R. R., De Vos, P., Goodfellow, M., Grimont, P. A. D., Pfennig, N., Stackebrandt, E. \& Zavarzin, G. A. (1990). Report of the ad hoc committee on approaches to taxonomy within the Proteobacteria. Int J Syst Bacteriol 40, 213-215.

Osterman, B. \& Moriyón, I. (2006). International Committee on Systematics of Prokaryotes; Subcommittee on the taxonomy of Brucella: Minutes of the meeting, 17 September 2003, Pamplona, Spain. Int J Syst Evol Microbiol 56, 1173-1175.

Ross, H. M., Foster, G., Reid, R. J., Jahans, K. L. \& MacMillan, A. P. (1994). Brucella species infection in sea-mammals. Vet Rec 134, 359.

Scholz, H. C., Tomaso, H., Al Dahouk, S., Witte, A., Schloter, M., Kämpfer, P., Falsen, E. \& Neubauer, H. (2006). Genotyping of Ochrobactrum anthropi by recA-based comparative sequence, PCRRFLP, and 16S rRNA gene analysis. FEMS Microbiol Lett 257, $7-16$.

Skerman, V. B. D., McGowan, V. \& Sneath, P. H. A. (editors) (1980). Approved lists of bacterial names. Int J Syst Bacteriol 30, 225-420.

Skerman, V. B. D., McGowan, V. \& Sneath, P. H. A. (editors) (1989). Approved Lists of Bacterial Names (Amended Edition). Washington, DC: American Society for Microbiology.

Sohn, A. H., Probert, W. S., Glaser, C. A., Gupta, N., Bollen, A. W., Wong, J. D., Grace, E. M. \& McDonald, W. C. (2003). Human neurobrucellosis with intracerebral granuloma caused by a marine mammal Brucella spp. Emerg Infect Dis 9, 485-488.

Stackebrandt, E., Fredriksen, W., Garrity, G. M., Grimont, P. A. D., Kämpfer, P., Maiden, M. C. J., Nesme, X., Rosselló-Mora, R., Swings, J. $\&$ other authors (2002). Report of the ad hoc committee for the reevaluation of the species definition in bacteriology. Int J Syst Evol Microbiol 52, 1043-1047.

Tindall, B. J., Kämpfer, P., Euzéby, J. P. \& Ohren, A. (2006). Valid publication of names of prokaryotes according to the rules of nomenclature: past history and current practice. Int J Syst Evol Microbiol 56, 2715-2720.

Verger, J.-M. \& Grayon, M. (1977). Oxidative metabolic profiles of "Brucella" species. Ann Sclavo 19, 46-60. 
Verger, J.-M., Grimont, F., Grimont, P. A. D. \& Grayon, M. (1985) Brucella, a monospecific genus as shown by deoxyribonucleic acid hybridization. Int J Syst Bacteriol 35, 292-295.

Verger, J.-M., Grimont, F., Grimont, P. A. D. \& Grayon, M. (1987). Taxonomy of the genus Brucella. Ann Inst Pasteur Microbiol 138, 235-238.

Verger, J.-M., Grayon, M., Cloeckaert, A., Lefèvre, M., Ageron, E. \& Grimont, F. (2000). Classification of Brucella strains isolated from marine mammals using DNA-DNA hybridization and ribotyping. Res Microbiol 151, 797-799.
Vizcaíno, N., Caro-Hernández, P., Cloeckaert, A. \& Fernández-Lago, L. (2004). DNA polymorphism in the omp25/omp31 family of Brucella spp.: identification of a 1.7-kb inversion in Brucella cetaceae and a 15.1$\mathrm{kb}$ genomic island, absent from Brucella ovis, related to the synthesis of smooth lipopolysaccharide. Microbes Infect 6, 821-834.

Wayne, L. G., Brenner, D. J., Colwell, R. R., Grimont, P. A. D., Kandler, O., Krichevsky, M. I., Moore, L. H., Moore, W. E. C., Murray, R. G. E. \& other authors (1987). International Committee on Systematic Bacteriology. Report of the ad hoc committee on reconciliation of approaches to bacterial systematics. Int J Syst Bacteriol 37, 463-464. 